\title{
The peculiarities of off-label use of drugs in pediatrics
}

\author{
S. M. Drohovoz ${ }^{\mathbb{D}}{ }^{1, D}$, Ya. 0. Butko ${ }^{1, E}$, L. B. Ivantsyk ${ }^{1, B}$, C. H. Shchokina ${ }^{1, A}$, \\ H. V. Bielik ${ }^{1, c}$, V. D. Lukianchuk ${ }^{2, F}$ \\ ${ }^{1}$ National University of Pharmacy, Kharkiv, Ukraine, ${ }^{2}$ Institute Pharmacology and Toxicology NAMS of Ukraine, Kyiv
}

A - research concept and design; B - collection and/or assembly of data; C - data analysis and interpretation; D - writing the article;

$\mathrm{E}$ - critical revision of the article; $\mathrm{F}$ - final approval of the article

Key words:

pediatrics,

pharmacotherapy,

off-label use.

\section{Zaporozhye}

medical journal

2020; $22(5), 714-718$

*E-mail:

drogovozsm@gmail.com

Prescribing drugs is not an easy task for pediatricians since the range of choice of drugs in pediatrics is $2 / 3$ less than in adult patients.

The aim of this work is to analyze the literature data on the experience of using off-label drugs in pediatrics in the world.

Materials and methods. Bibliographic analysis, literature review, statistical analysis.

Results. Based on the analysis, it was found that one of the most important reasons for off-label drug prescribing in children is the lack of standard, licensed, and safe therapeutic options for clinical trials of drugs in some diseases or conditions in children. Possible approaches to solving problems of "off-lable use" of drugs in medicine and health care are presented.

Conclusions. Off-label drug use in children can be improved by reports from pediatricians of pediatric experience with various off-label drugs in the form of scientific articles or discussions at scientific conferences, or with high levels of evidence. When deciding on the prescription of an off-label drug to a child, doctors should be sure that this is the only correct step, provided that there is a national form and a national list of essential medicines.

Ключові слова:

педіатрія, фармакотерапія, off label use.

Запорізький медичний журнал 2020. T. 22, № 5(122) C. $714-718$

\section{Особливості застосування ціків off-label у педіатрії}

\section{С. М. Ароговоз, Я. О. Бутко, А. Б. Іванцик, К. Г. Щокіна, Г. В. Бєлік, В. А. Аук'янчук}

Призначення препаратів - непросте завдання для педіатрів, оскільки асортимент вибору ліків у педіатрії на 2/3 менший, ніж у дорослих хворих.

Мета роботи - проаналізувати відомості фрахової літератури щодо досвіду застосування ліків off-label у педіатрії світу.

Матеріали та методи. Бібліосемантичний аналіз, огляд літератури, статистичний аналіз.

Результати. На підставі аналізу встановили, що однією з найважливіших причин призначення ліків off label «поза інструкцією» дітям $€$ відсутність стандартних, ліцензованих і безпечних терапевтичних варіантів клінічних випробувань ліків при деяких захворюваннях або станах у дітей. Наведені можливі підходи до розв'язання проблем «off lable use» ліків у медицині та охороні здоров'я.

Висновки. Ситуацію використання ліків off label у дітей можна поліпшити завдяки інформуванню лікарів про педіатричний досвід із різними ліками off label у вигляді наукових статей або обговорень на наукових конференціях, або з високим ступенем доказовості. Ухвалюючи рішення про призначення ліків off label дитині, лікарі повинні бути впевнені, що це єдиний правильний крок за умови наявності національного формуляра та національного переліку основних лікарських засобів.

Киючевые слова: педиатрия, фармакотерапия, off-label use.

\section{Запорожский} медицинский журнал. 2020. T. 22, № 5(122). C. 714-718

\section{Особенности применения лекарств off-label в педиатрии}

\section{С. М. Ароговоз, Я. А. Бутко, А. Б. Иванцик, Е. Г. Щекина, Г. В. Белик, В. А. Аукьянчук}

Назначение препаратов - непростая задача для педиатров, так как ассортимент выбора лекарств в педиатрии на 2/3 меньше, чем у взрослых больных.

Цель работы - проанализировать данные научной литературы об опыте применения лекарств off-label в мировой педиатрии

Материалы и методы. Библиосемантический анализ, обзор литературы, статистический анализ.

Результаты. На основе проведенного анализа установлено, что одна из наиболее важных причин назначения лекарств off-label «вне инструкции» детям - отсутствие стандартных, лицензированных и безопасных терапевтических вариантов клинических испытаний лекарств при некоторых заболеваниях или состояниях у детей. Приведены возможные подходы к решению проблем «оff-lable use» лекарств в медицине и здравоохранении.

Выводы. Ситуацию использования лекарств off-label у детей можно улучшить благодаря сообщениям врачей о педиатрическом опыте с различными лекарствами off-label в виде научных статей, обсуждений на научных конференциях, с высокой степенью доказательности. Принимая решение о назначении лекарств off-label ребенку, врачи должны быть уверены, что это единственный правильный шаг при условии наличия национального формуляра и национального перечня основных лекарственных средств. 
For over 35 years, the international scientific medical community has been trying to address the problem of off-label use of medicines. In pediatric pharmacotherapy, the use of approved drugs is usually optimal in terms of medical tactics, ethics and interests of the sick child. Prescribing is not an easy task for pediatricians, since the range of medicines in pediatrics is $2 / 3$ smaller than in adult patients. However, in the absence of drugs approved by the Food and Drug Administration (FDA) in the USA, the $\mathrm{MOH}$ in Ukraine, the physician is sometimes forced to use the off-label drug based on his or her own experience or compelling scientific evidence.

\section{Aim}

The aim of this work is to analyze literature data on the experience of off-label drug use in pediatrics in the world.

\section{Materials and methods}

In order to carry out this goal, the article used bibliosemantic, literature review and statistical analysis of literature data.

\section{Results}

Today, only about $20 \%$ of drugs in the USA approved by the FDA are indicated in the pediatric instructions [1-5]. Therefore, in pediatric practice, the use of off-label drugs is the rule rather than the exception. This is due to the fact that the traditional way of introducing medicines into pediatric practice is different from the usual approval of medicines for an adult patient and involves several steps [6]. Firstly, when newly registered, medicines are only allowed for use in adults, and secondly, authorization for clinical trials of medicines in children is granted only when their efficacy and safety in adult patients is confirmed. Therefore, most of the medicines (65-80\%) are not tested in children $[7,8]$.

In addition, one of the most important reasons for use of off-label drugs in children is not always the availability of up-to-date, standard, licensed, and safe therapeutic options for clinical trials of medicines for a particular disease or condition in children [9]. Secondly, laboratory procedures in clinical trials that seem technically simple for adults (blood test or urine sample) can cause difficulties and discomfort in children. Ethical and legal issues in children are also difficult or not always resolvable: adults can give informed consent to participate in a clinical trial and children can not, because "consent" means a full understanding of the potential risks of taking new investigational drugs.

According to the GCP (Good Clinical Practice) requirements, parents decide to participate in clinical trials of new drugs for children under 7 years of age. However, about $59.8 \%$ of the parents surveyed will allow their children to participate in clinical trials only if the disease is life-threatening. On the other hand, $40.2 \%$ of respondents would only agree to a clinical trial if their child developed a chronic or serious disease [5]. Therefore, despite measures aimed at increasing the number of clinical trials of medicines involving children taken by USA and EU regulators, the number remains limited [4].
Therefore, common reasons for using off-label drugs in pediatric practice are:

1) for the purpose of saving the life of a child;

2) use in the age group of patients for whom the product has not been approved;

3) use of a drug that has not been approved for a particular disease, when most drugs in the same pharmacological group have been approved for the treatment of such a disease;

4) the practice of using off-label drugs in pediatrics typically begins as soon as a new drug enters the pharmaceutical market $[4,10]$.

In view of the above, pediatricians often use the common off-label antibiotic approach, which is to use adult data but adjust doses depending on the child's weight or age $[11,12]$. The results of the analysis of the off-label drugs use in pediatrics showed that most often drugs are used off-label at a dose different from the recommended one. However, changing the dosage of the medicine can pose potential risks to both a patient and a doctor: the drug can be used in an insufficient or too high dose for the child, which in turn can lead to the problem of treatment ineffectiveness or drug overdoses $[1,5,9,11]$. In addition, it should also be remembered that pharmacokinetics and pharmacodynamics of drugs in children, unlike adults, can have significant differences in different age groups, which can significantly affect their effectiveness and cause adverse effects of their use [13].

Therefore, most data on pharmacodynamics and drug indications for use of their off-label in pediatrics are derived from clinical use in adult patients, but the full extrapolation of such data to children is not entirely correct. Therefore, in order to change the off-label medication instruction for children, there is sufficient clinical evidence to support the use of this drug in a specific age group of patients.

In 2014, Kathleen Neville, a chairwoman of the American Academy of Pediatrics (AAP), stated in her recommendations that "Pediatricians prescribe off-label drugs because the vast majority of much needed drugs still have no information in the instructions for use in children. This poses a particular problem for premature infants as well as children with chronic or rare diseases". However, according to the AAP, off-label therapy in pediatrics does not suggest improper or experimental drug use. Pediatricians who care for children may make therapeutic decisions on the use of off-label drugs based on the opinion of clinical experts or scientific evidence for the use of drugs in another age group [11].

The AAP recommends creating and implementing a common pediatric electronic database of off-label medicines, since available post-marketing pediatric reference marketing information is mainly focused on the positive experience of off-label medicines, and information about potentially unfavorable uses [11,12]. The AAP recommends the pediatricians to speak at conferences reporting the experience of using off-label drugs in children, and supports the publication of off-label drug research results in academic journals, including negative results, and recommends that such publications be used cautiously, especially when traditional therapy is ineffective. That is why the number of clinical trials in children in the United States from 2002 to 2012 exceeded the number of similar clinical trials conducted during the previous 50 
years. In the USA, it is not prohibited by any law to treat with off-label drug only if it's proved by the FDA $[9,12,13]$. The FDA has made more than 500 changes to the pediatric drugs instructions. These changes are an extension of both pediatric information in off-label drugs instructions and a knowledge base that practitioners can use to justify their therapeutic decisions [14-17].

Various national and international studies indicate that the rate of off-label drugs using can range from $18 \%$ to $60 \%$ in infants and up to $90 \%$ in newborns, whereas today, most drugs used in adults, children and adolescents, and especially newborns, are not licensed [11,18-21].

There are many publications around the world about the use of off-label drugs in children. Thus, in the USA, Europe and Australia, there are a large proportion of off-label prescriptions: in pediatric hospitals, the frequency of such drug use ranges from $72 \%$ to $93 \%$. The frequency of off-label drugs was determined by age: the highest (76 \%) - in the age group of 1 to 2 years, then (69\%) - in the group of 1 to 12 months [10,22-25].

Therefore, the practice of prescribing off-label drugs in pediatrics is widespread, despite the potential risks for children and doctors. Therefore, today is the time to change the legislation and introduce regulations in pediatrics in this area of pharmacotherapy. In the light of the foregoing, the need to strictly regulate and carry out research on off-label drugs in children should be recognized in order to ensure the safety and efficacy of pharmacotherapy.

From a legal and ethical point of view, the shaky balance between regulatory efforts to protect young patients from dangerous or ineffective drugs, on one hand, and the physician's prerogative to apply their professional knowledge and experience to treating small patients, on the other hand, is the basis for the use of drugs beyond approved indications in pediatrics.

Off-label prescribing is authorized for doctors in the United Kingdom. The British General Medical Council allows the prescription of off-label medicines, provided that they have greater benefits than detriments in the testimony and have sufficient scientific evidence for their safety and efficacy [3]. Particular attention is given to the dosage of drugs, which potentially have the risk of adverse reactions and may cause harm to sick children $[3,10,13]$.

Till date, in Europe and elsewhere, only about $35 \%$ of medicines on the pharmaceutical market are allowed for use in children [7]. When analyzing a comprehensive multicenter clinical trial, the use of off label drugs in pediatric practice in the EU, covering 30 countries (27 of which are EU Member States), found the most common use of off-label drugs in the 0 to 28 days age group, and also for children under 2 years $[4,7,22]$. The above analysis also shows that progress on the use of off-label medicines for newborns has been made since the adoption of the EU resolution in 2007. This period may have been very short for significant changes, especially for preterm infants, whose survival rates have increased significantly in recent years [26]. The 2010 European Pediatric Resolution helped increase clinical trials in children, but still, despite the need for clinical trials of preterm and term infants, only a limited number of clinical trials included such a group of pediatric patients. Therefore, the European Medical Academy (EMA) identified the research data as high priority. In addition, the EMA has approved a list of priority medicines off the label, which is updated annually, for study in various pediatric age groups $[27,28]$.

In Russia, the use of off-label drugs in children is performed by the following criteria:

- existence of a serious disease that threatens life or impairs quality of life;

- the absence in the age group of medicines registered as indicated for the treatment of this disease;

- scientific evidence of a curative or palliative effect when using this drug $[29,30]$.

In 2007, the WHO adopted a resolution on "Best Medicines for Children" to improve the monitoring of the safety of medicines, including those used off the label, for different age groups of children. In particular, in 2007, a special directive of the EU recommended that pharmaceutical companies introduce new medicines, including those used off label in children, and since the procedure for obtaining a registration certificate is a lengthy process, the manufacturer is granted a 10-year research privilege to assign an on-label status to off-label medicines (as instructed) [31].

Thus, conditions for the study and expansion of indications for the use of off-label drugs have been created for European pharmaceutical companies. However, there are still no specific official documents in the world that would specifically legalize the use of off-label drugs in pediatrics. Currently, the WHO believes that the situation of off-label drug use in children can be improved by reporting to doctors about pediatric experience with various off-label drugs in the form of scientific articles or discussions at scientific conferences with high levels of evidence for such drugs. Doctors should be aware of the latest data on the use of off-label medicines published in formats, collections, and innovative journals of clinical pharmacology $[31,32]$. Only such deliberate and coordinated actions will ensure that children are entitled to safe, therapeutically effective and cost-effective off-label medicines. The WHO believes that the use of off-label drugs is neither an experiment nor a clinical trial of these drugs, but it must be based on sound scientific knowledge (evidence). However, the principles of the off-label drugs use are contrary to current licensing standards. At the same time, the argument for the use of off-label drugs is that a doctor cannot prescribe drugs to a patient that would be ineffective and harmful. The legal basis in medicine and pharmacy obliges drug manufacturers to conduct clinical trials in children if the drug is intended for further use in this category of patients $[1,29,30,32]$. Children have the right to receive safe and effective medicines with the proper level of evidence, at the appropriate dose and route of administration for approved indications. Only close collaboration between all those involved in the approval and administration of off-label drugs in children will ensure that pediatric patients do not remain "therapeutic orphans" [26].

The use of off-label drugs in pediatric practice remains an urgent problem in medicine and pharmacy. Progress in the treatment of children cannot be achieved without controlled clinical trials to investigate the efficacy and safety of pediatric drugs [33]. Expanding indications and age ranges, exploring new dosage regimens and routes of administration to children should be considered as one of the priority areas of medicine and pharmaceutical companies [32]. 


\section{Conclusions}

Today, practitioners and pharmacists can make a significant contribution to addressing this problem by timely informing the Ministry of Pharmacovigilance of the Ministry of Health of Ukraine of adverse reactions of all medicines, including the use of off-label medicines. It is also a state-social problem that child forms of these drugs exist in other countries and are not purchased in Ukraine. Considering bioethical norms, it is necessary to extend the instruction of adult medicines for children only if in any country of the world there are no authorized forms of pediatric release, and the disease of the child threatens his life and all medicines available in Ukraine do not help.

When deciding on the prescription of an off-label drug to a child, doctors should be sure that this is the only correct step, provided that there is a national form and a national list of essential medicines. Thus, the ideal pediatric off-label pharmacotherapy remains a worldwide problem for regulatory organizations, physicians and pharmacists.

Conflicts of interest: authors have no conflict of interest to declare. Конфлікт інтересів: віАсутній.

Надійшла Ао реАакції / Received: 14.01.2020

Після Аоопрацювання / Revised: 11.03.2020

Прийнято Ао Аруку / Accepted: 31.03.2020

Information about authors:

Drohovoz S. M., MD, PhD, DSc, Professor of the Department of Pharmacology, National University of Pharmacy, Kharkiv, Ukraine. ORCID ID: 0000-0002-9997-2197

Butko Ya. O., PhD, DSc, Professor of the Department of Pharmacology, National University of Pharmacy, Kharkiv, Ukraine. ORCID ID: 0000-0001-6019-6330

Ivantsyk L. B., PhD, Assistant of the Department of Pharmacology, National University of Pharmacy, Kharkiv, Ukraine.

Shchokina C. H., PhD, DSc, Professor of the Department of

Pharmacology, National University of Pharmacy, Kharkiv, Ukraine. ORCID ID: 0000-0003-3297-5999

Bielik H. V., PhD, Associate of Professor of the Department of Pharmacology, National University of Pharmacy, Kharkiv, Ukraine. ORCID ID: 0000-0001-7207-2036

Lukianchuk V. D., MD, PhD, DSc, Head of the Department of Pharmacokinetics, Institute Pharmacology and Toxicology NAMS of Ukraine, Kyiv.

\section{Відомості про авторів:}

Ароговоз С. М., А-р меА. наук, професор каф. фармакології, Національний фармацевтичний університет, м. Харків, Україна. Бутко Я. О., А-р фарм. наук, професор каф. фармакології, Національний фармацевтичний університет, м. Харків, Україна. Іванцик А. Б., канА. фарм. наук, асистент каф. фармакології, Національний фармацевтичний університет, м. Харків, Україна. Щокіна К. Г., А-р фарм. наук, професор каф. фармакології, Національний фармацевтичний університет, м. Харків, Україна. Бєлік Г. В., канА. фарм. наук, Аоцент каф. фармакології, Національний фармацевтичний університет, м. Харків, Україна. Лук'янчук В. А., А-р меА. наук, професор, зав. віАділу фармакокінетики, Інститут фармакології та токсикології НАМН України, м. Київ.

\section{Сведения об авторах:}

Ароговоз С. М., А-р меА. наук, профессор каф. фармакологии, Национальный фармацевтический университет, г. Харьков, Украина.

Бутко Я. А., А-р фарм. наук, профессор каф. фармакологии, Национальный фармацевтический университет, г. Харьков, Украина.
Иванцик А. Б., канд. фарм. наук, ассистент каф. фармакологии, Национальный фармацевтический университет, г. Харьков, Украина.

Щекина Е. Г., А-р меА. наук, профессор каф. фармакологии, Национальный фармацевтический университет, г. Харьков, Украина.

Белик Г. В., канА. фарм. наук, Аоцент каф. фармакологии, Национальный фармацевтический университет, г. Харьков, Украина.

^укьянчук В. А., А-р меА. наук, профессор, зав. отАелом фармакокинетики, Институт фармакологии и токсикологии НАМН Украины, г. Киев.

\section{References}

[1] Gillick, M. R. (2009). Controlling Off-Label Medication Use. Annals of Internal Medicine, 150(5), 344-347. https://doi.org/10.7326/0003-4819150-5-200903030-00108

[2] Laughon, M. M., Benjamin, D. K., Jr, Capparelli, E. V., Kearns, G. L. Berezny, K., Paul, I. M., Wade, K., Barrett, J., Smith, P. B., \& Cohen-Wolkowiez, M. (2011). Innovative clinical trial design for pediatric therapeutics. Expert Review of Clinical Pharmacology, 4(5), 643-652. https://doi.org/10.1586/ecp.11.43

[3] Lukianchuk, J. O. (2018). Side effects of off label drugs. Topical issues of new drugs development. Abstracts of XXV International Scientific And Practical Conference Of Young Scientists And Student (pp. 267). NUPh.

[4] Guidi, B., \& Nocco, L. (2011). The debate concerning the off-label prescriptions of drugs: a comparison between Italian and U.S. law. Opinio Juris in Comparatione, 1(1). http://www.opiniojurisincomparatione.org/ opinio/article/view/43

[5] Fabiano, V., Mameli, C., \& Zuccotti, G. V. (2012). Adverse drug reactions in newborns, infants and toddlers: pediatric pharmacovigilance between present and future. Expert Opinion on Drug Safety, 11(1), 95-105. https://doi.org/10.1517/14740338.2011.584531

[6] Komarova, A. P. (2017). Off-label use of drugs in children. Topical issues of new drugs development. Abstracts of XXIV International Scientific And Practical Conference Of Young Scientists And Student (Vol. 2, pp. 50-51). NUPh

[7] Jain, S. S., Bavdekar, S. B., Gogtay, N. J., \& Sadawarte, P. A. (2008). Off-label drug use in children. Indian Journal of Pediatrics, 75, Article 1133. https://doi.org/10.1007/s12098-008-0188-1

[8] Lee, J. H., Byon, H. J., Choi, S., Jang, Y. E., Kim, E. H., Kim, J. T. \& Kim, H. S. (2018). Safety and Efficacy of Off-label and Unlicensed Medicines in Children. Journal of Korean Medical Science, 33(37), Article e227. https://doi.org/10.3346/jkms.2018.33.e227

[9] Allen, H. C., Garbe, M. C., Lees, J., Aziz, N., Chaaban, H., Miller, J. L., Johnson, P., \& DeLeon, S. (2018). Off-Label Medication use in Children, More Common than We Think: A Systematic Review of the Literature. Journal of the Oklahoma State Medical Association, 111(8), 776-783.

[10] Shah, S. S., Hall, M., Goodman, D. M., Feuer, P., Sharma, V., Fargason, C., Jr, Hyman, D., Jenkins, K., White, M. L., Levy, F. H., Levin, J. E., Bertoch, D., \& Slonim, A. D. (2007). Off-label drug use in hospitalized children. Archives of Pediatrics \& Adolescent Medicine, 161(3), 282290. https://doi.org/10.1001/archpedi.161.3.282

[11] Frattarelli, D. A., Galinkin, J. L., Green, T. P., Johnson, T. D., Neville, K. A., Paul, I. M., Van Den Anker, J. N., \& American Academy of Pediatrics Committee on Drugs. (2014). Off-label use of drugs in children. Pediatrics, 133(3), 563-567. https://doi.org/10.1542/peds.2013-4060

[12] Yackey, K., Stukus, K., Cohen, D., Kline, D., Zhao, S., \& Stanley, R. (2019). Off-label Medication Prescribing Patterns in Pediatrics: An Update. Hospital Pediatrics, 9(3), 186-193. https://doi.org/10.1542/ hpeds.2018-0168

[13] Palčevski, G., Skočibušić, N., \& Vlahović-Palčevski, V. (2012). Unlicensed and off-label drug use in hospitalized children in Croatia: a cross-sectional survey. European Journal of Clinical Pharmacology, 68(7), 1073-1077. https://doi.org/10.1007/s00228-012-1221-x

[14] Rogers, J. (2008). Freedom of Speech and the FDA's Regulation of Off-Label Drug Uses. The George Washington Law Review, 76(5), 1429-1443. http://www.gwlr.org/wp-content/uploads/2012/08/76-5-Rogers.pdf

[15] Stafford, R. S. (2008). Regulating Off-Label Drug Use - Rethinking the Role of the FDA. The New England Journal of Medicine, 358(14), 1427-1429. https://doi.org/10.1056/NEJMp0802107

[16] Yackey, K., \& Stanley, R. (2019). Off-Label Prescribing in Children Remains High: A Call for Prioritized Research. Pediatrics, 144(4), Article e20191571. https://doi.org/10.1542/peds.2019-1571

[17] Czaja, A. S., Reiter, P. D., Schultz, M. L., \& Valuck, R. J. (2015). Patterns of Off-Label Prescribing in the Pediatric Intensive Care Unit and Prioritizing Future Research. The Journal of Pediatric Pharmacology and Therapeutics, 20(3), 186-196. https://doi.org/10.5863/1551-6776-20.3.186 
[18] Palmaro, A., Bissuel, R., Renaud, N., Durrieu, G., Escourrou, B., Oustric, S., Montastruc, J. L., \& Lapeyre-Mestre, M. (2015). Off-label prescribing in pediatric outpatients. Pediatrics, 135(1), 49-58. https:// doi.org/10.1542/peds.2014-0764

[19] Aagaard, L. (2015). Off-Label and Unlicensed Prescribing of Medicines in Paediatric Populations: Occurrence and Safety Aspects. Basic \& Clinical Pharmacology \& Toxicology, 117(4), 215-218. https://doi. org/10.1111/bcpt.12445

[20] Teigen, A., Wang, S., Truong, B. T., \& Bjerknes, K. (2017). Off-labe and unlicensed medicines to hospitalised children in Norway. The Journal of Pharmacy and Pharmacology, 69(4), 432-438. https://doi. org/10.1111/jphp.12581

[21] Tefera, Y. G., Gebresillassie, B. M., Mekuria, A. B., Abebe, T. B. Erku, D. A., Seid, N., \& Beshir, H. B. (2017). Off-label drug use in hospitalized children: a prospective observational study at Gondar University Referral Hospital, Northwestern Ethiopia. Pharmacology Research \& Perspectives, 5(2), Article e00304. https://doi.org/10.1002/prp2.304

[22] Mühlbauer, B., Janhsen, K., Pichler, J., \& Schoettler, P. (2009). Off-label use of prescription drugs in childhood and adolescence: an analysis of prescription patterns in Germany. Deutsches Arzteblatt International, 106(3), 25-31. https://doi.org/10.3238/arztebl.2009.0025

[23] Landwehr, C., Richardson, J., Bint, L., Parsons, R., Sunderland, B., \& Czarniak, P. (2019). Cross-sectional survey of off-label and unlicensed prescribing for inpatients at a paediatric teaching hospital in Western Australia. PLOS ONE, 14(1), Article e0210237. https://doi.org/10.1371/ journal.pone.0210237

[24] Panther, S. G., Knotts, A. M., Odom-Maryon, T., Daratha, K., Woo, T., \& Klein, T. A. (2017). Off-label Prescribing Trends for ADHD Medications in Very Young Children. The Journal of Pediatric Pharmacology and Therapeutics, 22(6), 423-429. https://doi.org/10.5863/1551-6776-22.6.423

[25] Mulligan, E., \& Messenger, H. (2011). Mifepristone in South Australia the first 1343 tablets. Australian Family Physician, 40(5), 342-352.

[26] Kimland, E., \& Odlind, V. (2012). Off-label drug use in pediatric patients. Clinical Pharmacology \& Therapeutics, 91(5), 796-801. https://doi. org/10.1038/clpt.2012.26

[27] Roberts, G., Xatzipsalti, M., Borrego, L. M., Custovic, A., Halken, S. Hellings, P. W., Papadopoulos, N. G., Rotiroti, G., Scadding, G., Timmermans, F., \& Valovirta, E. (2013). Paediatric rhinitis: position paper of the European Academy of Allergy and Clinical Immunology. Allergy, 68(9), 1102-1116. https://doi.org/10.1111/all.12235

[28] Sturkenboom, M. C., Verhamme, K. M., Nicolosi, A., Murray, M. L., Neubert, A., Caudri, D., Picelli, G., Sen, E. F., Giaquinto, C., Cantarutti, L., Baiardi, P., Felisi, M. G., Ceci, A., Wong, I. C., \& TEDDY European Network of Excellence. (2008). Drug use in children: cohort study in three European countries. British Medical Journal, 337, Article a2245. https://doi.org/10.1136/bmi.a2245

[29] Tsygankova, O. V., Batluk, T. I., Latyntseva, L. D., Platonov, D. Y., \& Akhmedzhanov, N. M. (2019). Yuridicheskie i meditsinskie aspekty naznacheniya lekarstvennykh sredstv vne instruktsii. Tochka zreniya [Legal and Medical Aspects of Off-Label Medication Use. Point of View]. Ratsional'naya Farmakoterapiya v Kardiologii, 15(1), 130-134. https://doi.org/10.20996/1819-6446-2019-15-1-130-134 [in Russian].

[30] Mustafina-Bredikhina, D. M. (2015). Primenenie lekarstvennykh preparatov off-label: mezhdunarodnyi opyt i perspektivy v Rossii [Off-label prescription drugs use: international practice and perspectives on Russia]. Neonatologiya: novosti, mneniya, obuchenie, (1), 77-79. [in Russian].

[31] Molyneux, C. G., \& Bogaert, P. (2010, 25 October). The need for informed consent in off label use in the EU. Pharma Intelligence. https://pink.pharmaintelligence.informa.com/PS115666/The-need-forinformed-consent-in-offlabel-use-in-the-EU

[32] Mason, J., Pirmohamed, M., \& Nunn, T. (2012). Off-label and unlicensed medicine use and adverse drug reactions in children: a narrative review of the literature. European Journal of Clinical Pharmacology, 68(1), 21-28. https://doi.org/10.1007/s00228-011-1097-1

[33] Czarniak, P., Bint, L., Favié, L., Parsons, R., Hughes, J., \& Sunderland, B. (2015). Clinical Setting Influences Off-Label and Unlicensed Prescribing in a Paediatric Teaching Hospital. PLOS ONE, 10(3), Article e0120630. https://doi.org/10.1371/journal.pone.0120630 